\title{
Oral manifestations, dental management, and a rare homozygous mutation of the PRDM12 gene in a boy with hereditary sensory and autonomic neuropathy type VIII: a case report and review of the literature
}

Karim Elhennawy ${ }^{1}$, Seif Reda ${ }^{1}$, Christian Finke ${ }^{1}$, Luitgard Graul-Neumann²,3, Paul-Georg Jost-Brinkmann ${ }^{1}$ and Theodosia Bartzela ${ }^{1 *}$

\begin{abstract}
Background: Hereditary sensory and autonomic neuropathy type VIII is a rare autosomal recessive inherited disorder. Chen et al. recently identified the causative gene and characterized biallelic mutations in the PR domaincontaining protein 12 gene, which plays a role in the development of pain-sensing nerve cells. Our patient's family was included in Chen and colleagues' study. We performed a literature review of the PubMed library (January 1985 to December 2016) on hereditary sensory and autonomic neuropathy type I to VIII genetic disorders and their orofacial manifestations. This case report is the first to describe the oral manifestations, and their treatment, of the recently discovered hereditary sensory and autonomic neuropathy type VIII in the medical and dental literature.

Case presentation: We report on the oral manifestations and dental management of an 8-month-old white boy with hereditary sensory and autonomic neuropathy-VIII over a period of 16 years. Our patient was homozygous for a mutation of PR domain-containing protein 12 gene and was characterized by insensitivity to pain and thermal stimuli, self-mutilation behavior, reduced sweat and tear production, absence of corneal reflexes, and multiple skin and bone infections. Oral manifestations included premature loss of teeth, associated with dental traumata and selfmutilation, severe soft tissue injuries, dental caries and submucosal abscesses, hypomineralization of primary teeth, and mandibular osteomyelitis.

Conclusions: The lack of scientific knowledge on hereditary sensory and autonomic neuropathy due to the rarity of the disease often results in a delay in diagnosis, which is of substantial importance for the prevention of many complications and symptoms. Interdisciplinary work of specialized medical and dental teams and development of a standardized treatment protocols are essential for the management of the disease. There are many knowledge gaps concerning the management of patients with hereditary sensory and autonomic neuropathy-VIII, therefore more research on an international basis is needed.
\end{abstract}

Keywords: Case report, Dental, PRDM12 gene, Hereditary sensory and autonomic neuropathy, HSAN-VIII, Oral manifestations

\footnotetext{
* Correspondence: theodosia.bartzela@charite.de

${ }^{1}$ Center for Dental and Craniofacial Sciences, Department of Orthodontics,

Dentofacial Orthopedics and Pedodontics, Charité - Universitätsmedizin

Berlin, Aßmannshauser Str. 4-6, 14197 Berlin, Germany

Full list of author information is available at the end of the article
} 


\section{Background}

Hereditary sensory and autonomic neuropathy (HSAN) comprises a group of genetic disorders involving sensory and autonomic dysfunctions [1]. HSAN was classified into five main types [2]. Later, it was modified into subtypes [3-5] according to gene mutations, mode of inheritance, and clinical characteristics. HSAN types VI and VII were mentioned in the classification of Haga et al. [5]: Online Mendelian Inheritance in Man (OMIM) 614653 and 615548 respectively. HSAN type VIII (OMIM 616488) was recently characterized by Chen et al. [6] as a rare autosomal recessive disorder. Our patient's family was included in their study. General characteristics, mode of inheritance, onset, and genes involved in each type of HSAN are presented in Table 1.

HSAN-VIII is characterized by five main features: insensitivity to pain and thermal stimuli, self-mutilation behavior, altered sweat and tear formation, absence of corneal reflexes, and presence of repeated infections of the skin and bone [6]. The syndrome was confirmed in 21 patients [6] and 10 different homozygous mutations in the PR domain-containing protein 12 gene (PRDM12) were identified [6]. Mutations in the PRDM12 gene in humans cause developmental defects in the sensory neurons, leading to loss of pain perception. Great loss of the small myelinated A $\delta$ fibers occurred in patients with HSAN-VIII. Skin biopsies revealed that the peripheral terminals of unmyelinated $C$ fibers were altered [6].

Patients carrying PRDM12 mutations lack the sensation of acute pain and temperature. Thus, these patients have numerous injuries, which may lead to recurrent infections of skin and bones, and bone deformities later in life. In addition, they lack corneal reflexes, which leads to progressive corneal scarring. However, other senses like light touch, vibration, and proprioception are normal. The only autonomic dysfunction observed was the reduction in sweating and tears formation. Intellectual abilities in patients with HSAN-VIII are normal [6].

Insensitivity to pain leads to severe oral mutilations, such as tooth luxation, severe dental attrition, premature tooth loss, bite wounds, and ulcerations [7-9]. The tongue, followed by the lips, and the oral mucosa, are the most common sites of self-inflicted injuries $[10,11]$. The diagnosis of HSAN is challenging due to its rarity, similarity in clinical presentation to other autoaggression or self-mutilation diseases, and lack of simple diagnostic tests [12]. It is mainly confirmed by the clinical presentation, genetic analysis, pharmacological tests, and neuropathological examinations [13]. Management of patients affected by HSAN-VIII is complicated due to the patients' lack of awareness and perception of pain.

We aimed to present the manifestations and dental management of a patient with HSAN-VIII harboring the homozygous mutation $c .516 G>C(p$. Glu172Asp) in the
PRDM12 gene [6], who has been followed up in our clinic for 16 years. A review on PubMed library (January 1985 to December 2016) on patients with HSAN with oral manifestations was performed (Table 2).

\section{Case presentation}

An 8-month-old white boy of Turkish origin initially presented to the Department of Pedodontics, at Charité - Universitätsmedizin Berlin Hospital, due to an unexplained early loss of his primary lower central incisors. He was the first child of healthy consanguineous parents (second-degree relatives); their younger daughter was healthy. Our patient had multiple injuries on his face and body and in his oral cavity due to self-mutilation (Fig. 1). Further medical history revealed that he was born with a bilateral foot deformity (Fig. 2), which resulted in the mandatory use of an orthopedic appliance, enabling him to walk normally (Fig. 3). At the age of 6 years and 2 months, he had a fracture in the metatarsal bone, leading to bone necrosis. This resulted in the placement of bone plates and the use of a wheelchair for long walking distances. He had several accidents, such as severe burns from boiling water without feeling any pain.

Prior to the first visit to the Department of Pedodontics at the age of 8 months, he had lost both mandibular primary central incisors for unknown reasons only 3 months after they erupted. His mandibular left lateral incisor was loose (mobility, grade 2). In addition, his mandibular left primary second molar (75) showed signs of enamel hypoplasia. He experienced no pain or discomfort during the dental procedures. A year later, he presented at our department due to the further loss of ten of his primary teeth (Fig. 4). The early loss of so many teeth raised suspicion of a systemic disorder. He was referred to the Department of Human Genetics at Charité - Universitätsmedizin Berlin. The following differential diagnoses of auto-aggression syndromes were suspected: congenital insensitivity to pain and anhidrosis (CIPA), Smith-Magenis syndrome, Lesch-Nyhan syndrome, or pantothenate kinase-associated neurodegeneration (PKAN). In addition, the following systemic diseases, which might cause premature loss of teeth, were suspected: Langerhans cell histiocytosis, hypophosphatasia, and Papillon-Lefèvre syndrome. The diagnosis of CIPA syndrome was thought to be closest to his condition. All other suspected auto-aggression syndromes and systemic diseases were excluded based on blood tests, genetic diagnosis, and further clinical examination. However, after deeper investigations, the diagnosis HSAN-VIII was considered the definitive diagnosis of our patient.

Partial dentures for maxilla and mandible were constructed to prevent speech impairment and to enhance his lower facial height (Fig. 5). Due to his high caries 


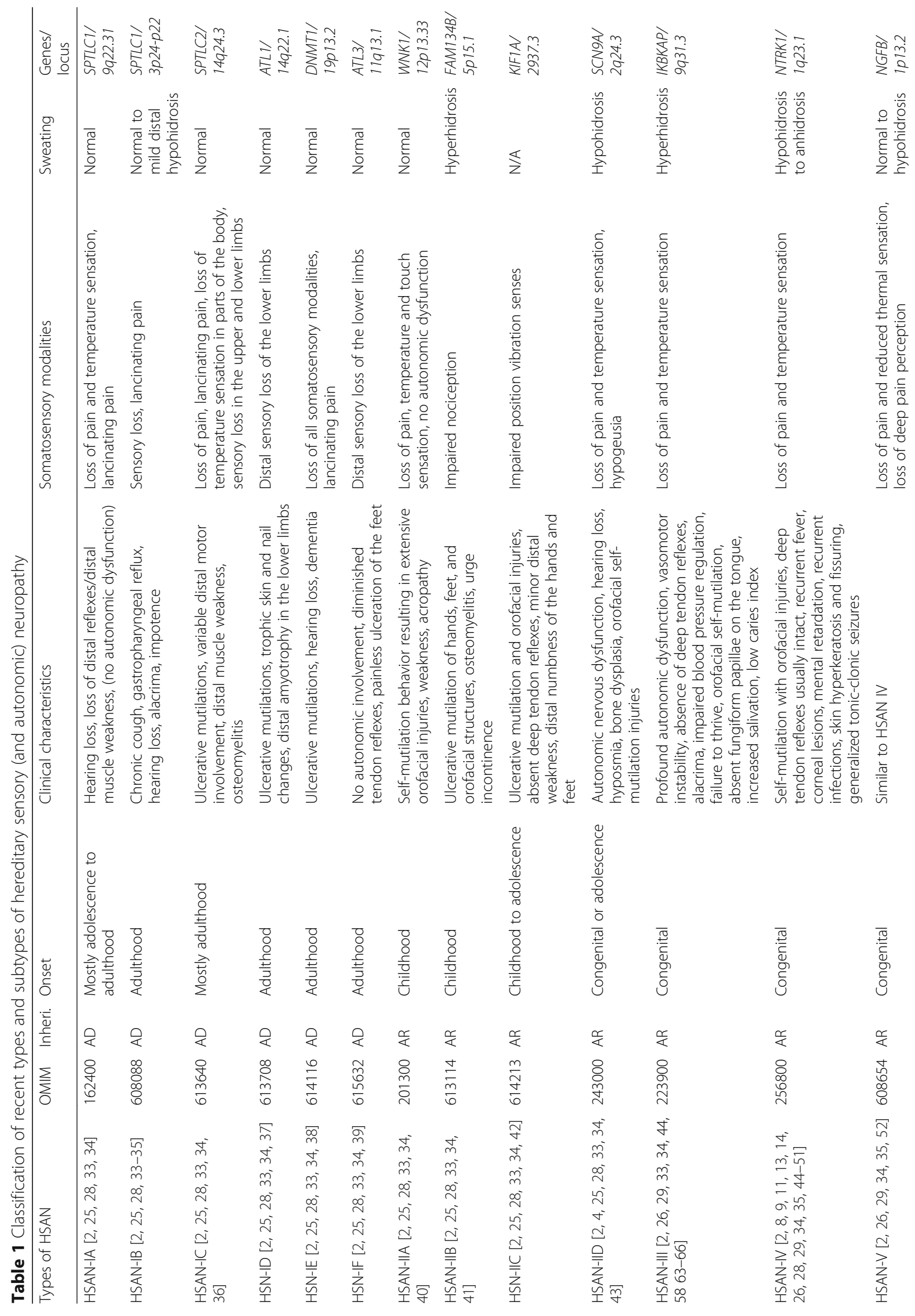




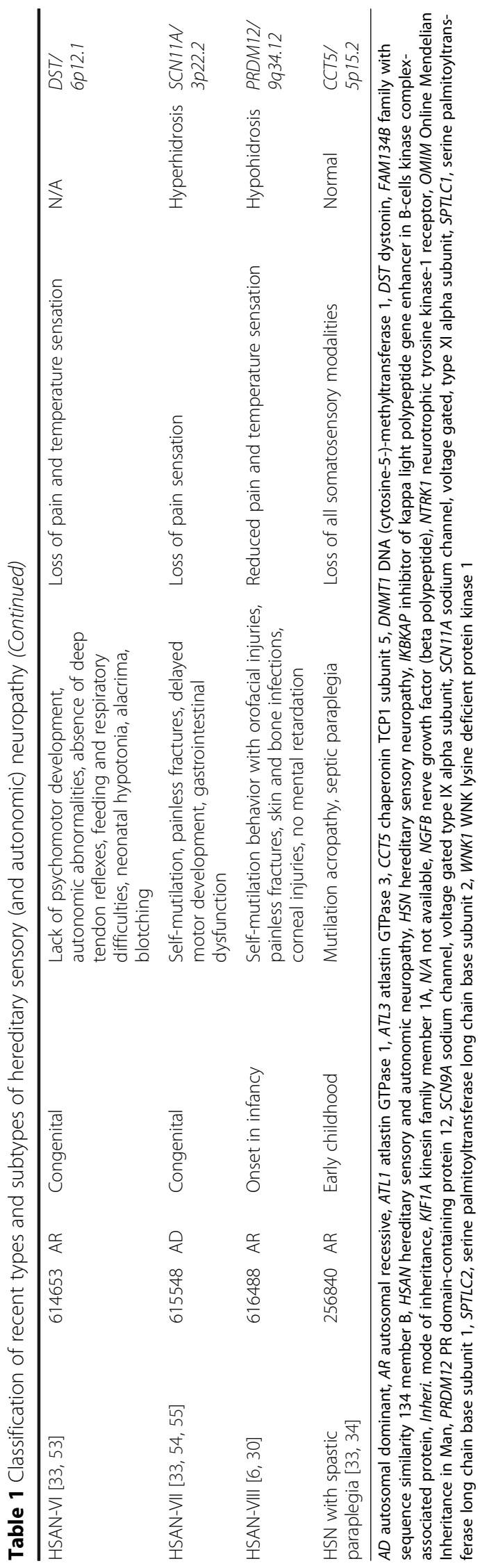




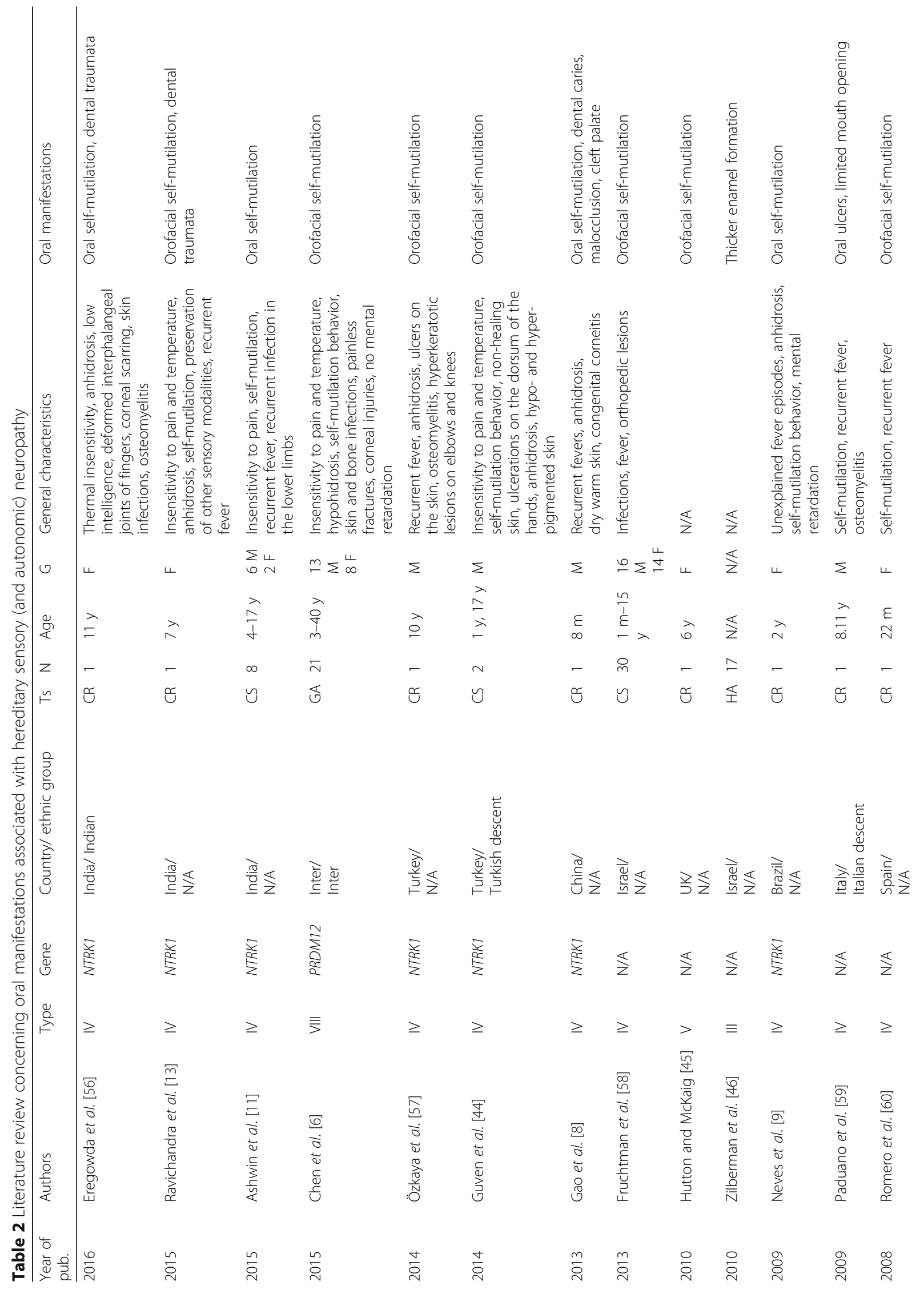




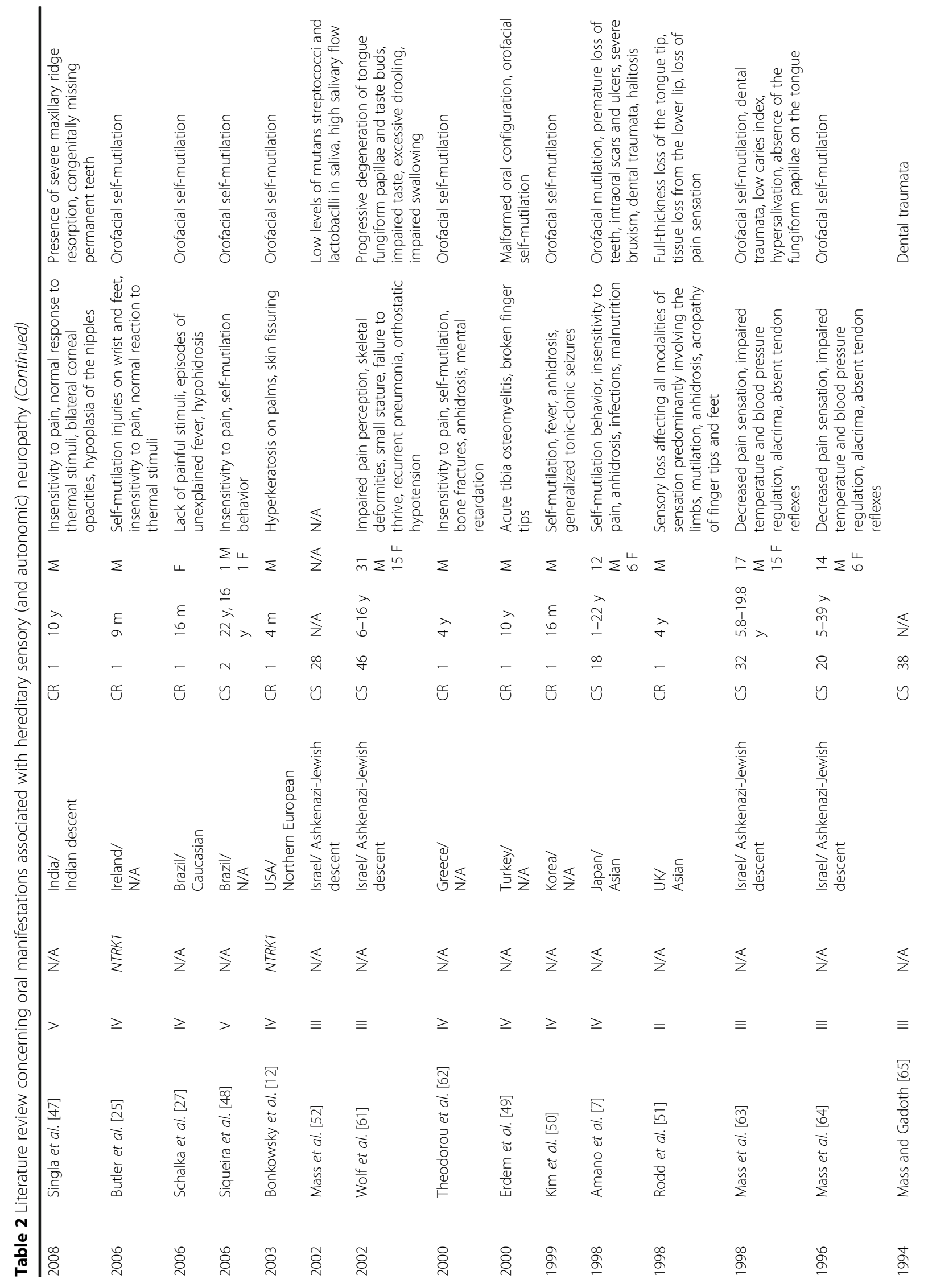




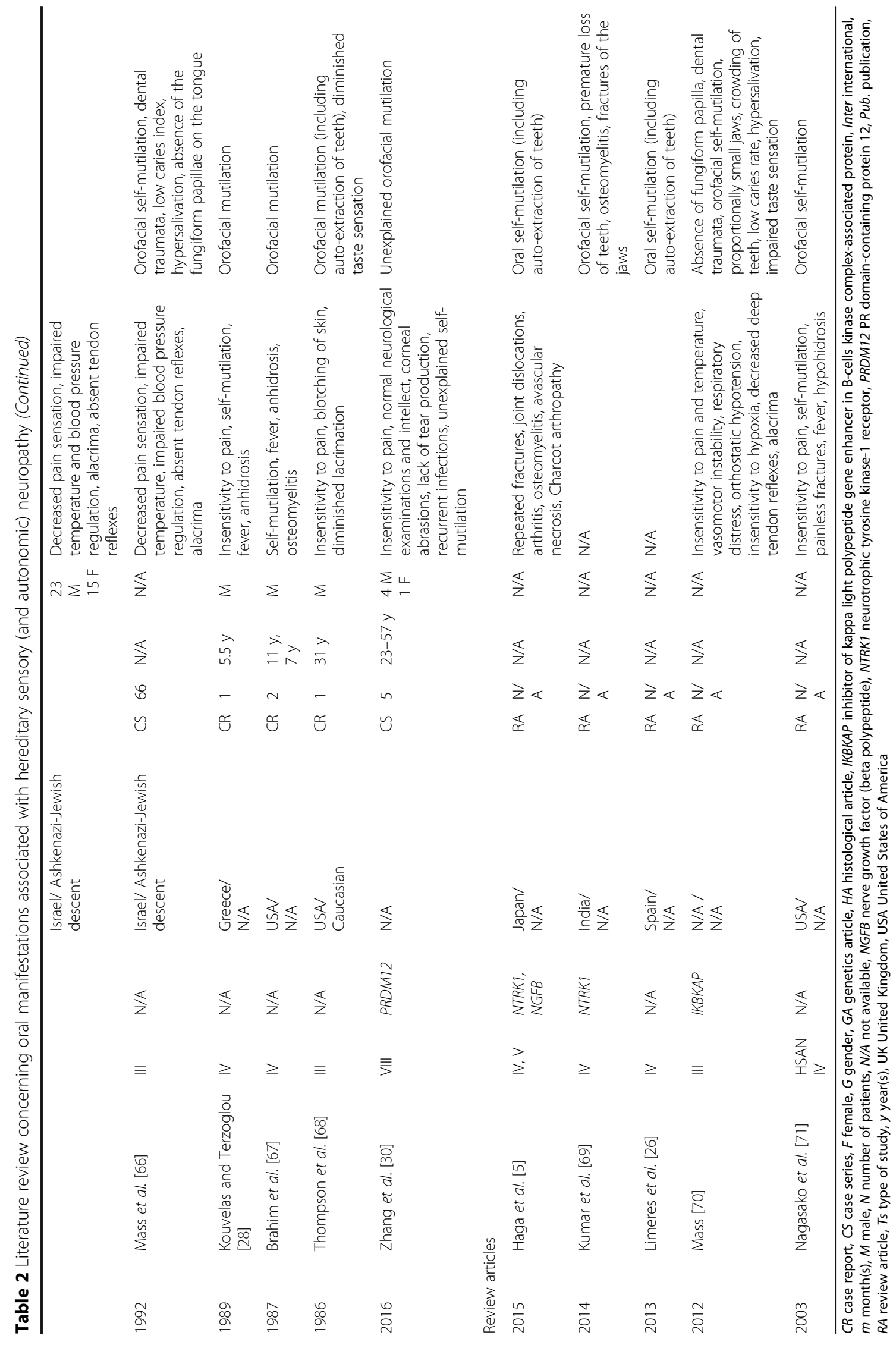




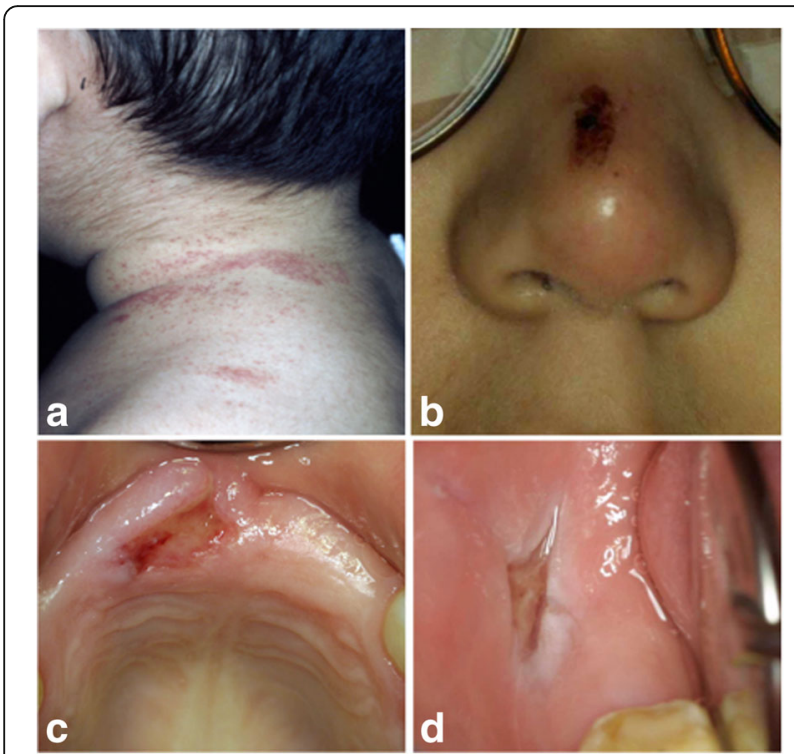

Fig. 1 Representation of self-mutilation. $\mathbf{a}+\mathbf{b}$ Extraoral selfmutilation. c+d Intraoral self-mutilation

activity, an intensive prophylaxis program with continuous follow-up was implemented to avoid further dental deterioration and improve his oral health status. Over the years, with the help of an interdisciplinary medical team and his parents, he has shown great cooperation and completely ceased any sort of self-mutilation behavior.

\section{Discussion}

The pediatric dentist was the first to refer our patient to the human genetics department with the suspicion of HSAN syndrome, based on the premature loss of primary teeth and self-mutilation behavior. The initial diagnosis of our patient of CIPA or HSAN-IV was not confirmed by molecular analysis, since it did not detect a mutation in the neurotrophic tyrosine kinase-1 receptor gene (NTRK1), which is the receptor for nerve

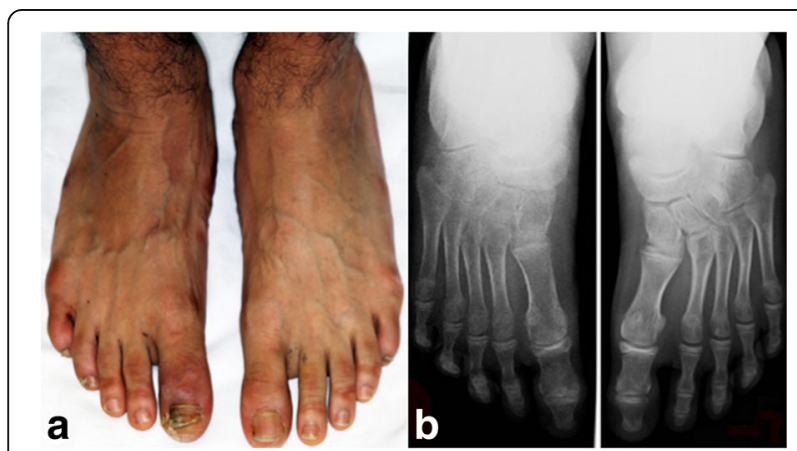

Fig. 2 Bilateral bone deformity of the feet. a Clinical presentation of the deformed feet. $\mathbf{b}$ Radiographic presentation of the deformed feet

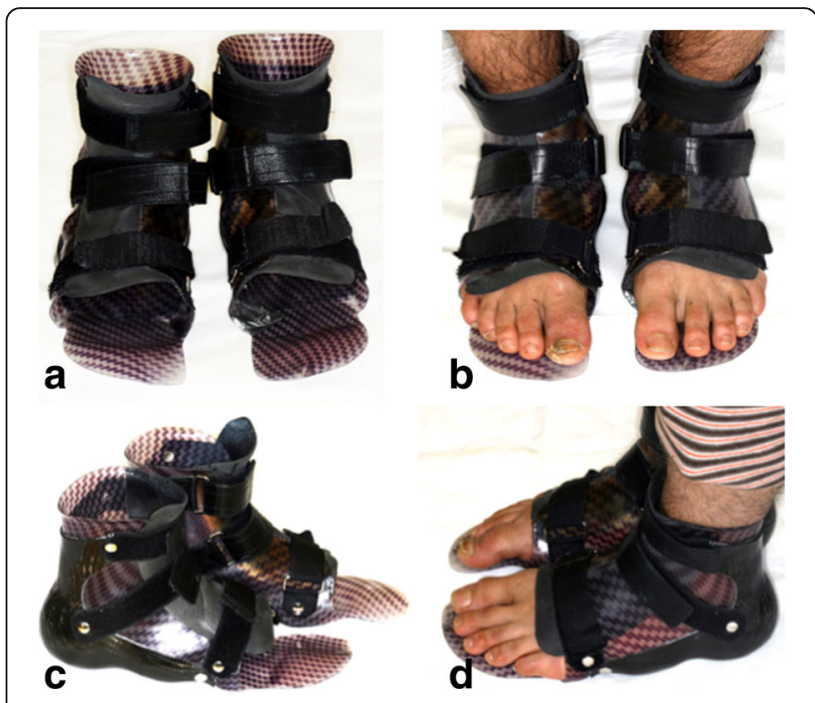

Fig. 3 Orthopedic appliance used to support the patient's feet during walking. a+c Orthopedic appliance. $\mathbf{b}+\mathbf{d}$ Patient wearing his orthodontic appliance

growth factor (NGF) related to CIPA syndrome [12]. Our patient harbored a homozygous mutation in the recently discovered gene PRDM12 [6]. Therefore, HSAN-VIII was his final diagnosis. Deoxyribonucleic acid (DNA) sequencing of the parents confirmed the segregation of the mutation in the family. The mode of inheritance was autosomal recessive [6]. Self-mutilation behavior is one of the most outstanding characteristics of HSAN syndrome. However, it is also common in other auto-aggression diseases, which makes the diagnosis challenging. Smith-Magenis syndrome was a differential diagnosis concerning the self-inflicted injuries [14], but a causative 17p.11.2 microdeletion was excluded by fluorescence in situ hybridization. As for Lesch-Nyhan syndrome, patients have dystonia and ballism [15], which were not symptoms of our patient. Further analysis did not reveal defects in the hypoxanthineguanine phosphoribosyltransferase (HPRT) enzyme, confirming the false diagnosis. PKAN is also characterized

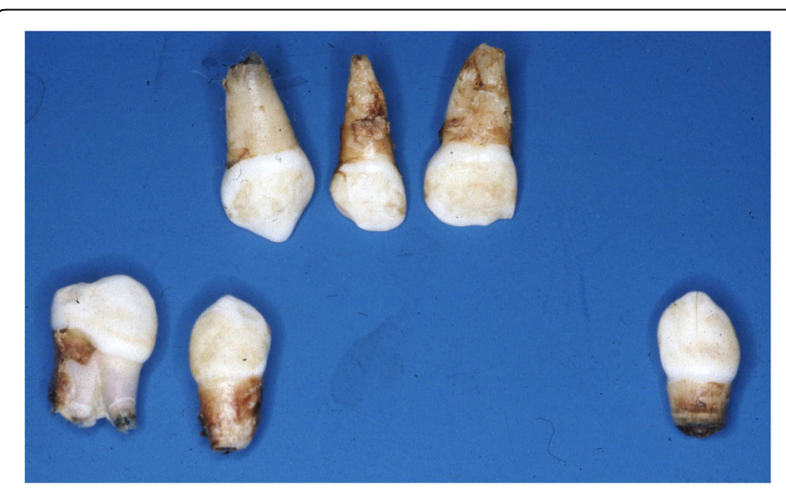

Fig. 4 Auto-extracted teeth of the patient 


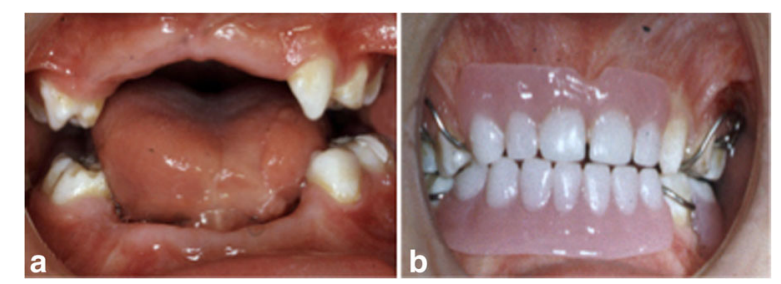

Fig. 5 Prosthodontic treatment of the patient. $(\mathbf{a}+\mathbf{b})$ Intraoral pictures of patient without and with prostheses, respectively

by dystonia and therefore was ruled out [16-19]. Blood tests excluded the systemic diseases of Langerhans cell histiocytosis and hypophosphatasia [20]. Hypophosphatasia was also excluded because of our patient's normal total serum alkaline phosphatase activity [21-23]. Papillon-Lefèvre syndrome was not confirmed due to the absence of the diffuse palmoplantar hyperkeratosis and the progressive periodontitis [24]. Oral manifestations of HSAN are important, since they are one of the first complaints presented by affected patients. They can be detected early in life, starting with the eruption of the primary dentition [25]. Because of the variability and rarity of the clinical presentation of HSAN, no standard dental management protocols have been established. Patients with HSAN should be treated individually [26]. The dental treatment planning can be affected by several factors, such as age, mental development, and patient's and parents' compliance [27]. In the 1960s, the treatment approach for patients with HSAN was extraction of all primary teeth and construction of dentures in order to prevent self-mutilation. Nowadays, there are many dental treatment options for the prevention of self-mutilating behavior, varying from the elimination of sharp tooth surfaces by grinding or restoring them with resin composite, to the use of intraoral appliances such as mouthguards. Since the self-mutilation behavior of patients with HSAN-VIII starts in infancy, it may prove difficult to use intraoral appliances at that point. However, tooth extractions should be considered the last line of treatment. Early loss of teeth is one of the most frequent dental complications of HSAN. It is important to be able to deal with its consequences, such as speech impairment and increased incidence of malocclusions $[25,26,28]$. Professional dental cleaning, behavioral management, and routine check-up appointments were the cornerstones of our treatment plan. Prevention of dental disease is required in patients with HSAN, since caries progression and pulpal involvement can occur without causing any pain or discomfort. The parents of patients with HSAN play a crucial role in the management of the condition, since their psychological support is necessary to help the child understand his or her condition and prevent further injuries $[27,28]$. The most critical phase of managing patients with HSAN would be building an understanding of the emotional experience of pain. A psychological approach should be introduced as early as possible [27]. Cognitive behavioral models for self-management and distress regulation have been proposed [29].

The literature search revealed that HSAN-IV (CIPA) is the most discussed form of HSAN in dentistry. Selfmutilation and auto-aggression are the first and most common clinical characteristics in all mentioned HSAN types (Table 2). The literature review results mainly consisted of case reports and case series, which is understandable due to the rarity of the syndrome. In contrast to our case report, a long follow-up period was not reported in the majority of publications. Our case report is, to the best of our knowledge, the first to discuss the oral manifestations and management of HSAN-VIII. Zhang et al. [30] also reported on the clinical characteristics of five patients with HSAN-VIII and was in line with Chen et al. [6]. The clinical characteristics described by Zhang et al. [30] that were found in all patients were: insensitivity to pain, normal neurological examinations and intellect, corneal abrasions, lack of tear production, recurrent infections, and unexplained oral self-mutilation (especially tongue injuries). There is a need for further dental and medical management solutions for these patients, as well as for well-educated practitioners [29]. There are many obstacles that have to be overcome since often there is a lack of resources for research and international collaboration and for accessible database and diagnostic and treatment tools. By expanding our knowledge on genetic and epigenetic factors that are critical for pain sensation, new fields are opened for therapeutic intervention in chronic and neuropathic pain conditions $[6,31,32]$.

\section{Conclusions}

HSAN-VIII is a rare, complex, recently identified condition mainly characterized by insensitivity to pain and thermal stimuli. The affected persons are vulnerable to various complications and in severe cases, selfmutilation can lead to death. Early identification of the disease is important to prevent all these consequences. The literature contains mainly case reports and case series of patients with HSAN, therefore, there are many knowledge gaps concerning preventive and therapeutic approaches. Treatment efficacy depends on educating the family and supporting the child psychologically. Moreover, an interdisciplinary treatment approach, in which there is medical and dental interdisciplinary cooperation, is required for such patients. A homozygous mutation of the PRDM12 gene, which is responsible for the HSAN-VIII condition, was identified in our patient. Mutations in this gene cause developmental defects in sensory neurons before their transition to nociceptors. 


\section{Abbreviations}

CIPA: Congenital insensitivity to pain and anhidrosis; HSAN-VIII: Hereditary sensory and autonomic neuropathy type VIII; NGF: Nerve growth factor; OMIM: Online Mendelian Inheritance in Man; NTRK1: Neurotrophic tyrosine kinase-1 receptor; PKAN: Pantothenate kinase-associated neurodegeneration; PRDM12: PR domain-containing protein 12 gene

\section{Acknowledgements}

Not applicable.

\section{Funding}

This study was funded by the authors and their institutions.

\section{Availability of data and materials}

Data sharing is not applicable to this article as no datasets were generated or analyzed during the current study.

\section{Authors' contributions}

All authors have read and approved the final manuscript. LG is the human geneticist who did the genetic analysis and interpretation. CF, KE, and SR were the pediatric dentists of the patient. CF followed the dental treatment of the patient from 8 months of age until the present time. TB, PJ, and KE conceived and designed the work, reviewed the literature and the differential diagnosis, and delineated the critical point for the discussion. Al the authors gave their contribution to the drafting and critical review of the article.

\section{Ethics approval and consent to participate}

No ethical approval was needed. Informed consent was obtained from the patient's legal guardians involved in this study.

\section{Consent for publication}

Written informed consent was obtained from the patient's legal guardian(s) for publication of this case report and any accompanying images. A copy of the written consent is available for review by the Editor-in-Chief of this journal.

\section{Competing interests}

The authors declare that they have no competing interests.

\section{Publisher's Note}

Springer Nature remains neutral with regard to jurisdictional claims in published maps and institutional affiliations.

\section{Author details}

${ }^{1}$ Center for Dental and Craniofacial Sciences, Department of Orthodontics, Dentofacial Orthopedics and Pedodontics, Charité - Universitätsmedizin Berlin, Aßmannshauser Str. 4-6, 14197 Berlin, Germany. ${ }^{2}$ Ambulantes Gesundheitszentrum, Campus Virchow Clinic, Charité - Universitätsmedizin Berlin, Berlin, Germany. ${ }^{3}$ Charité Campus Virchow, Department of Human Genetics, Charité - Universitätsmedizin Berlin, Augustenburger Platz 1, 13353 Berlin, Germany.

Received: 1 March 2017 Accepted: 11 July 2017

Published online: 15 August 2017

\section{References}

1. Dearborn G. A case of congenital pure analgesia. J Nerv Ment Dis. 1932;75 612-5.

2. Dyck PJ, Mellinger JF, Reagan TJ, Horowitz SJ, McDonald JW, Litchy WJ, et al. Not 'indifference to pain' but varieties of hereditary sensory and autonomic neuropathy. Brain. 1983;106(Pt 2):373-90.

3. Rotthier A, Auer-Grumbach M, Janssens K, Baets J, Penno A, Almeida-Souza $L$, et al. Mutations in the SPTLC2 subunit of serine palmitoyltransferase cause hereditary sensory and autonomic neuropathy type I. Am J Hum Genet. 2010;87:513-22

4. Yuan J, Matsuura E, Higuchi Y, Hashiguchi A, Nakamura T, Nozuma S, et al. Hereditary sensory and autonomic neuropathy type IID caused by an SCN9A mutation. Neurology. 2013;80:1641-9.
5. Haga N, Kubota M, Miwa Z. Japanese Research Group on Congenital Insensitivity to Pain. Hereditary sensory and autonomic neuropathy types IV and $V$ in Japan. Pediatr Int. 2015;57:30-6.

6. Chen YC, Auer-Grumbach M, Matsukawa S, Zitzelsberger M, Themistocleous AC, Strom TM, et al. Transcriptional regulator PRDM12 is essential for human pain perception. Nat Genet. 2015;47:803-8.

7. Amano A, Akiyama S, Ikeda M, Morisaki I. Oral manifestations of hereditary sensory and autonomic neuropathy type IV. Congenital insensitivity to pain with anhidrosis. Oral Surg Oral Med Oral Pathol Oral Radiol Endod. 1998;86: 425-31.

8. Gao L, Guo H, Ye N, Bai Y, Liu X, Yu P, et al. Oral and craniofacial manifestations and two novel missense mutations of the NTRK1 gene identified in the patient with congenital insensitivity to pain with anhidrosis. PLoS One. 2013;8:e66863.

9. Neves BG, Roza RT, Castro GF. Traumatic lesions from congenital insensitivity to pain with anhidrosis in a pediatric patient: dental management. Dent Traumatol. 2009:25:545-9.

10. Bodner L, Woldenberg Y, Pinsk V, Levy J. Orofacial manifestations of congenital insensitivity to pain with anhidrosis: a report of 24 cases. ASDC Dent Child. 2002;69:293-6. 235

11. Ashwin DP, Chandan GD, Jasleen HK, Rajkumar GC, Rudresh KB, Prashanth R. Hereditary sensory and autosomal peripheral neuropathy-type IV: case series and review of literature. Oral Maxillofac Surg. 2015;19:117-23.

12. Bonkowsky JL, Johnson J, Carey JC, Smith AG, Swoboda KJ. An infant with primary tooth loss and palmar hyperkeratosis: a novel mutation in the NTRK1 gene causing congenital insensitivity to pain with anhidrosis. Pediatrics. 2003;112:e237-41.

13. Ravichandra KS, Kandregula CR, Koya S, Lakhotia D. Congenital insensitivity to pain and anhydrosis: diagnostic and therapeutic dilemmas revisited. Int $J$ Clin Pediatr Dent. 2015:8:75-81.

14. Girirajan S, Elsas LJ, Devriendt K, Elsea 2nd SH. RAl1 variations in SmithMagenis syndrome patients without 17p11.2 deletions. J Med Genet. 2005; 42:820-8.

15. Pozzi M, Piccinini L, Gallo M, Motta F, Radice S, Clementi E. Treatment of motor and behavioural symptoms in three Lesch-Nyhan patients with intrathecal baclofen. Orphanet J Rare Dis. 2014;9:208.

16. Brunetti D, Dusi S, Morbin M, Uggetti A, Moda F, D'Amato I, et al. Pantothenate kinase-associated neurodegeneration: altered mitochondria membrane potential and defective respiration in Pank2 knock-out mouse model. Hum Mol Genet. 2012;21:5294-305.

17. Gregory A, Hayflick SJ, et al. Pantothenate Kinase-Associated Neurodegeneration. In: Pagon RA, Adam MP, Ardinger HH, Wallace SE Amemiya A, Bean LJH, editors. GeneReviews(R). Seattle: University of Washington, Seattle University of Washington, Seattle; 1993. All rights reserved.

18. Gregory A, Hayflick SJ. PANK2 mutation screening recommended to confirm diagnosis of pantothenate kinase-associated neurodegeneration. AJNR Am J Neuroradiol. 2006;27:951.

19. Yapici Z, Akcakaya NH, Tekturk P, Iseri SA, Ozbek U. A novel gene mutation in PANK2 in a patient with severe jaw-opening dystonia. Brain Dev. 2016; 38(8):755-8.

20. Calming $U$, Henter $\mathrm{J}$. Elevated erythrocyte sedimentation rate and thrombocytosis as possible indicators of active disease in Langerhans' cell histiocytosis. Acta Paediatr. 1998;87:1085-7.

21. Fraser D. Hypophosphatasia. Am J Med. 1957;22:730-46.

22. Jaruratanasirikul S, Chanvitan P. Hypophosphatasia: the importance of alkaline phosphatase in bone mineralization. J Med Assoc Thai. 1999;82: 1268-72.

23. Reibel A, Maniere MC, Clauss F, Droz D, Alembik Y, Mornet E, et al. Orodental phenotype and genotype findings in all subtypes of hypophosphatasia. Orphanet J Rare Dis. 2009;4:6.

24. Dhanrajani PJ. Papillon-Lefevre syndrome: clinical presentation and a brief review. Oral Surg Oral Med Oral Pathol Oral Radiol Endod. 2009;108:e1-7.

25. Butler J, Fleming P, Webb D. Congenital insensitivity to pain - review and report of a case with dental implications. Oral Surg Oral Med Oral Pathol Oral Radiol Endod. 2006:101:58-62

26. Limeres J, Feijoo JF, Baluja F, Seoane JM, Diniz M, Diz P. Oral self-injury: an update. Dent Traumatol. 2013:29:8-14.

27. Schalka MM, Correa MS, Ciamponi AL. Congenital insensitivity-to-pain with anhidrosis (CIPA): a case report with 4-year follow-up. Oral Surg Oral Med Oral Pathol Oral Radiol Endod. 2006;101:769-73. 
28. Kouvelas N, Terzoglou C. Congenital insensitivity to pain with anhidrosis: case report. Pediatr Dent. 1989;11:47-51.

29. Graham CD, Gouick J, Krahe C, Gillanders D. A systematic review of the use of Acceptance and Commitment Therapy (ACT) in chronic disease and long-term conditions. Clin Psychol Rev. 2016;46:46-58.

30. Zhang S, Sharif SM, Chen YC, Valente EM, Ahmed M, Sheridan E, Bennett C, Woods $\mathrm{G}$. Clinical features for diagnosis and management of patients with PRMD12 congenital insensitivity to pain. J Med Genet. 2016;53:533-5.

31. Crow M, Denk F, McMahon SB. Genes and epigenetic processes as prospective pain targets. Genome Med. 2013;5:12.

32. Denk F, McMahon SB. Chronic pain: emerging evidence for the involvement of epigenetics. Neuron. 2012;73:435-44.

33. Haga N, Kubota M, Miwa Z. Epidemiology of hereditary sensory and autonomic neuropathy type IV and V in Japan. Am J Med Genet A. 2013; 161A:871-4

34. Rotthier A, Baets J, Timmerman V, Janssens K. Mechanisms of disease in hereditary sensory and autonomic neuropathies. Nat Rev Neurol. 2012;8:73-85.

35. Kok C, Kennerson ML, Spring PJ, Ing AJ, Pollard JD, Nicholson GA. A locus for hereditary sensory neuropathy with cough and gastroesophageal reflux on chromosome 3p22-p24. Am J Hum Genet. 2003;73:632-7.

36. Penno A, Reilly MM, Houlden $H$, Laura M, Rentsch K, Niederkofler $V$, et al. Hereditary sensory neuropathy type 1 is caused by the accumulation of two neurotoxic sphingolipids. J Biol Chem. 2010;285:11178-87.

37. Guelly C, Zhu PP, Leonardis L, Papic L, Zidar J, Schabhuttl M, et al. Targeted high-throughput sequencing identifies mutations in atlastin-1 as a cause of hereditary sensory neuropathy type I. Am J Hum Genet. 2011;88:99-105.

38. Klein CJ, Botuyan MV, Wu Y, Ward CJ, Nicholson GA, Hammans S, et al. Mutations in DNMT1 cause hereditary sensory neuropathy with dementia and hearing loss. Nat Genet. 2011;43:595-600.

39. Kornak U, Mademan I, Schinke M, Voigt M, Krawitz P, Hecht J, et al. Sensory neuropathy with bone destruction due to a mutation in the membraneshaping atlastin GTPase 3. Brain. 2014;137:683-92.

40. Lafreniere RG, MacDonald ML, Dube MP, MacFarlane J, O'Driscoll M, Brais B, et al. Identification of a novel gene (HSN2) causing hereditary sensory and autonomic neuropathy type II through the Study of Canadian Genetic Isolates. Am J Hum Genet. 2004;74:1064-73.

41. Ilgaz Aydinlar E, Rolfs A, Serteser M, Parman Y. Mutation in FAM134B causing hereditary sensory neuropathy with spasticity in a Turkish family. Muscle Nerve. 2014;49:774-5.

42. Riviere JB, Ramalingam S, Lavastre V, Shekarabi M, Holbert S, Lafontaine J, et al. KIFIA, an axonal transporter of synaptic vesicles, is mutated in hereditary sensory and autonomic neuropathy type 2. Am J Hum Genet. 2011;89:219-30.

43. Cox JJ, Reimann F, Nicholas AK, Thornton G, Roberts E, Springell K, et al. An SCN9A channelopathy causes congenital inability to experience pain. Nature. 2006;444:894-8.

44. Guven Y, Altunoglu U, Aktoren O, Uyguner ZO, Kayserili H, Kaewkahya M, et al. Twins with hereditary sensory and autonomic neuropathy type IV with preserved periodontal sensation. Eur J Med Genet. 2014;57:240-6.

45. Hutton A, McKaig S. The dental management of a child with congenital insensitivity to pain. Dent Update. 2010;37:180-2. 185.

46. Zilberman U, Zilberman S, Keinan D, Elyiahu M. Enamel development in primary molars from children with familial dysautonomia. Arch Oral Biol. 2010;55:907-12.

47. Singla S, Marwah N, Dutta S. Congenital insensitivity to pain (hereditary sensory and autonomic neuropathy type V): a rare case report. J Dent Child (Chic). 2008;75:207-11.

48. Siqueira SR, Okada M, Lino AM, Teixeira MJ, Siqueira JT. Proposal for a standardized protocol for the systematic orofacial examination of patients with Hereditary Sensory Radicular Neuropathy. Int Endod J. 2006;39:905-15.

49. Erdem TL, Ozcan I, llguy D, Sirin S. Hereditary sensory and autonomic neuropathy: review and a case report with dental implications. J Oral Rehabil. 2000;27:180-3.

50. Kim JS, Woo YJ, Kim GM, Kim CJ, Ma JS, Hwang TJ, et al. Congenital insensitivity to pain with anhidrosis: a case report. J Korean Med Sci. 1999;14:460-4.

51. Rodd HD, Loescher AR, Boissonade FM. Immunocytochemical and electronmicroscopic features of tooth pulp innervation in hereditary sensory and autonomic neuropathy. Arch Oral Biol. 1998:43:445-54.

52. Mass E, Gadoth N, Harell D, Wolff A. Can salivary composition and high flow rate explain the low caries rate in children with familial dysautonomia? Pediatr Dent. 2002;24:581-6.
53. Edvardson S, Cinnamon Y, Jalas C, Shaag A, Maayan C, Axelrod FB, et al. Hereditary sensory autonomic neuropathy caused by a mutation in dystonin. Ann Neurol. 2012;71:569-72.

54. Leipold E, Liebmann L, Korenke GC, Heinrich T, Giesselmann S, Baets J, et al. A de novo gain-of-function mutation in SCN11A causes loss of pain perception. Nat Genet. 2013:45:1399-404.

55. Woods CG, Babiker MO, Horrocks I, Tolmie J, Kurth I. The phenotype of congenital insensitivity to pain due to the NaV1.9 variant p.L811P. Eur J Hum Genet. 2015;23:1434.

56. Eregowda NI, Yadav S, Parameshwarappa P, Basavraj RK. A Girl with No Pain: Congenital Insensitivity To Pain and Anhidrosis (HSAN) Type IV - A Case Report. J Clin Diagn Res. 2016;10:Z101-02.

57. Ozkaya AK, Guler E, Arik E, Namli AR, Cevizli D, Gungor O. A case of congenital insensitivity to pain with anhidrosis. Turk Pediatri Ars. 2014;49:177-9.

58. Fruchtman Y, Perry ZH, Levy J. Morbidity characteristics of patients with congenital insensitivity to pain with anhidrosis (CIPA). J Pediatr Endocrinol Metab. 2013;26:325-32.

59. Paduano S, lodice G, Farella M, Silva R, Michelotti A. Orthodontic treatment and management of limited mouth opening and oral lesions in a patient with congenital insensitivity to pain: case report. J Oral Rehabil. 2009;36:718.

60. Romero M, Simon R, Garcia-Recuero Jl, Romance A. Dental management of oral self-mutilation in neurological patients: a case of congenital insensitivity to pain with anhidrosis. Med Oral Patol Oral Cir Bucal. 2008;13:E644-647.

61. Wolff A, Harell D, Gadoth N, Mass E. Submandibular and sublingual salivary gland function in familial dysautonomia. Oral Surg Oral Med Oral Pathol Oral Radiol Endod. 2002;94:315-9.

62. Theodorou SD, Klimentopoulou AE, Papalouka E. Congenital insensitivity to pain with anhidrosis. Report of a case and review of the literature. Acta Orthop Belg. 2000;66:137-45.

63. Mass E, Brin I, Belostoky L, Maayan C, Gadoth N. A cephalometric evaluation of craniofacial morphology in familial dysautonomia. Cleft Palate Craniofac J. 1998:35:120-6.

64. Mass E, Zilberman U, Gadoth N. Abnormal enamel and pulp dimensions in familial dysautonomia. J Dent Res. 1996;75:1747-52.

65. Mass E, Gadoth N. Oro-dental self-mutilation in familial dysautonomia. J Oral Pathol Med. 1994:23:273-6.

66. Mass E, Sarnat H, Ram D, Gadoth N. Dental and oral findings in patients with familial dysautonomia. Oral Surg Oral Med Oral Pathol. 1992;74:305-11.

67. Brahim JS, Roberts MW, McDonald HD. Oral and maxillofacial complications associated with congenital sensory neuropathy with anhydrosis: report of two cases. J Oral Maxillofac Surg. 1987;45:331-4.

68. Thompson BH, Hartwell GR, Ekvall WM, Koudelka BM. Endodontic management of a patient with familial dysautonomia. J Endod. 1986;12:170-3.

69. Kumar A, Naik P, Jaishankar HP. Congenital insensitivity to pain: Review with dental implications. Indian J Pain. 2014;28:13.

70. Mass E. A review of the oro-dento-facial characteristics of hereditary sensory and autonomic neuropathy type III (familial dysautonomia). Spec Care Dentist. 2012;32:15-20.

71. Nagasako EM, Oaklander AL, Dworkin RH. Congenital insensitivity to pain: an update. Pain. 2003;101:213-9.

\section{Submit your next manuscript to BioMed Central and we will help you at every step:}

- We accept pre-submission inquiries

- Our selector tool helps you to find the most relevant journal

- We provide round the clock customer support

- Convenient online submission

- Thorough peer review

- Inclusion in PubMed and all major indexing services

- Maximum visibility for your research

Submit your manuscript at www.biomedcentral.com/submit
Biomed Central 